aan te twijfelen, ook al komt bij een tweede onderzoek een collega met nieuwe feiten en een andere winstberekening voor den dag. Het komt in ons ,bedrijf" wel meer voor dat het masker bij de eerste stoot scheef komt te staan en pas bij een volgende wordt weggeslagen.

Het is best mogelijk en het komt zeker voor bij bedrijven waarvan de administratie van ons standpunt bezien aan de ,zwakke kant" is, dat de eerste bel. accountant gegevens verzamelt, om extra-comptabel de fiscale credietwaardigheid t.z.t. te toetsen.

Aangezien me tijdens de accountantsstudie een hevige afkeer voor steekproeven is bijgebracht en me nog altijd een historische angst daarvoor is bijgebleven, geneer ik me een beetje openhartig te verklaren, dat de bel. accountant die nog niet heeft afgeschaft.

Blijkt b.v. uit een steekproef dat er bij een afnemer van de in arrest 6782 genoemde $A$. te $X$ geen ,evenwicht" tussen de beide administraties is, dan kan de boekhouding van $A$. technisch nog zo verzorgd lijken, maar dan is er toch alle reden om gewapend met nadere gegevens een nieuw boekenonderzoek in te stellen.

De Hoge Raad kent zijn Pappenheimers zo langzamerhand wel en is zich terecht terdege bewust dat er omissies kunnen zijn, welke niet direct bij de eerste diagnose van den eerlijken "Sijmen" zullen blijken. Het zou toch wel een beetje absurd zijn als deze de fiscale dokter, die later met een verbeterd operatief instrumentarium op komt dagen, de deur zou kunnen wijzen, met een beroep op de verjaring van zijn kwaal.

Dat er tussen het eerste en het tweede accountantsonderzoek een geruime tijd is verlopen zegt ook niets, want de bel. accountant holt niet als een detective van den een naar den ander om te constateren of de verklaringen over en weer wel kloppen, maar wacht als regel totdat de cliënt voor boekenonderzoek aan de beurt is gekomen.

Overigens komt het om tactische of andere reden vaak voor, dat een collega een tweede boekenonderzoek ter hand neemt, want de bel. accountant - en dit is ook een verschilpunt met de collega's in het vrije beroep - houdt er persoonlijk geen vaste cliënten op na.

J. L. VAN DER PAUW. Bel. accountant.

\section{STATISTISCH ONDERZOEK INZAKE RENTABILITEITSVERBETERING VAN ZWEMBADEN}

\section{II *)}

In het vorig artikel hebben wij de diagnose gesteld en deze ook quantitatief bepaald, terwijl wij vervolgens de te nemen maatregelen hebben aangegeven. De derde stap vormde een practische uitwerking van een tariefsysteem met vastrecht voor een zwembad. Alvorens hiertoe over te kumnen gaan moesten wij door middel van een eenvoudige enquête eenig inzicht in de zwemgewoonte verkrijgen. Dit op grond van onderstaande overwegingen. ${ }^{1}$ )

\section{A. Doel van de enquête.}

Doel van de enquête was gegevens te verkrijgen voor het

*) I in de Mei-aflevering van deze jaargang, blz. 86 e.v.

1) Het kwam ons geschikt voor op sommige punten van de practische uitwerking van de enquête wat uitvoerig in te gaan. In Nederland vindt. in tegenstelling met de U.S.A., de enquête ten behoeve van bedrijfsgegevens nog betrekkelijk weinig toepassing. Aan de eene kant willen wij aangeven hoe op eenvoudige wijze een enquête gehouden kan worden, aan de andere kant tevens wijzen op de moeilijkheden die zich daarbij voordoen. vaststellen van de zgn. „overwipgrenzen”. Het belangrijkste gegeven hiervoor is het gemiddeld aantal baden, dat per bezoeker per jaar genomen wordt. Rechtstreeksche vaststelling van dit aantal was alleen mogelijk bij abonnementhouders. Behalve vragen naar het aantal baden per jaar werden vragen gesteld naar leeftijd, gebruikte tarief en het aantal gezinsleden, dat van het zwembad gebruik maakt.

\section{B. Voorbereiding.}

Een enquête dient grondig voorbereid te worden. Deze voorbereiding betreft:

1. Vragenlijst.

2. Enquête omvang en -periode, met het doel een zoo juist mogelijk beeld (,fair sample") te krijgen.

\section{Ad. 1: Vragenlijst.}

Hieronder is een formulier afgedrukt zooals dit voor het onderzoek gebruikt is. Invulling geschiedt waar mogelijk door aanstrepen van een voorgedrukt antwoord. Dit voorkomt be halve een verkeerd begrijpen van de vraag veel werk bij het verwerken van de antwoorden. Dit verwerken kan nu practisch automatisch geschieden.

TER BEVORDERING VAN DE ZWEMSPORT VERZOEKEN WIJ U BELEEFD, DE VOLGENDE VRAGEN TE BEANTWOORDEN. (Het betreffend antwoord aanstrepen)

1. Naam ..................... Voorletter 2. Man|Vrouw

3. Leeftijdsklasse \begin{tabular}{|l|l|l|l|l|l|}
\hline $0-5$ & $6-12$ & $13-18$ & $19-30$ & $31-50$ & 51 en hooger \\
\hline
\end{tabular}

4. Van welk tarief Jaarabonn. 1/2 Jaarabonn. Maandabonn. Spaard.knipkaart maakt U gebruik?

\begin{tabular}{|c|c|c|c|}
\hline \multicolumn{2}{|c|}{ Groepsabonn. a ....... } & \multicolumn{2}{c|}{ Los bad à ........ } \\
\hline $\begin{array}{c}\text { Coupon- } \\
\text { boekje }\end{array}$ & $\begin{array}{c}10 \text { Badenk. } \\
\text { kinderen }\end{array}$ & $\begin{array}{c}\text { Vereeni- } \\
\text { gingen }\end{array}$ & Werkloozen \\
\hline
\end{tabular}

5. Hoeveel maal per jaar maakt U gebruik van dit zwembad?

6. Maken meerdere leden van het gezin, waartoe $U$ behoort gebruik van dit zwembad? \begin{tabular}{|l|l|}
\hline Ja & Neen \\
\hline
\end{tabular}

7. Zoo ja, hoeveel? ...........

Niet invullen

Datum ............ Uur ........... Bad ...........

\section{Ad. 2: Vaststelling van het "enquête-rooster".}

Zeer belangrijk is het, dat met de enquête een „Fair sample” verkregen wordt, m.a.w. dat het verkregen resultaat representatief is voor het geheel.

Op grond van aprioristische overwegingen zou het aanbeveling verdienen om gedurende een paar dagen in de zomer en een paar dagen in de winterperiode te enquêteeren.

Immers 's zomers zal men de categorie van baders, welke des zomers buiten zwemmen, niet treffen. Aan de andere kant zullen in de zomer weer bezoekers in het zwembad komen. welke des winters geen of weinig behoefte tot zwemmen gevoelen en die men dus in de wintermaanden niet met de enquête bereikt.

Urgentie van het rapport liet echter niet de keus open voor een geschikte enquête-periode in deze zin. De enquête moest zoo snel mogelijk gehouden worden en viel daardoor bovendien nog in het einde van de vacantie-periode.

Behalve deze verschillen tusschen zomer en winter zijn er verschillen tusschen de verschillende dagen van de week en de uren van de dag. Het was wel mogelijk om in een klein tijdsbestek met deze verschillen rekening te houden.

Gedurende de week voorafgaande aan de week van de 
enquête werden de bezoekcijlers geregistreerd en aan de hand daarvan werd het volgende enquête-rooster vastgesteld:

\begin{tabular}{|c|c|c|c|c|}
\hline \multirow{2}{*}{ Datum } & & \multirow{2}{*}{ Bad } & \multicolumn{2}{|c|}{$\begin{array}{c}\text { Bezoek in } \\
\text { voorafg. week }\end{array}$} \\
\hline & & & 'Totaal & $\begin{array}{l}\text { Daarvan } \\
\text { volw. }\end{array}$ \\
\hline \multirow[t]{3}{*}{ Vrijdag } & $\begin{array}{l}\text { Heeren } \\
\text { Dames }\end{array}$ & $\begin{array}{ll}\text { uur } & 7-9 \\
\text { uur } & 9-151 / 2\end{array}$ & $\begin{array}{r}85 \\
115\end{array}$ & $\begin{array}{l}20 \\
63\end{array}$ \\
\hline & Dames & tur $18-20,2$ & 93 & 49 \\
\hline & dames & uur $201 / 2-22$ & 117 & 117 \\
\hline Zaterdag & $\begin{array}{l}\text { Heeren } \\
\text { Dames } \\
\text { Heeren }\end{array}$ & $\begin{array}{l}\text { uur } 12-15 \\
\text { uur } 15-17 \\
\text { uur } 17-19\end{array}$ & $\begin{array}{r}99 \\
113 \\
83\end{array}$ & $\begin{array}{l}37 \\
83 \\
55\end{array}$ \\
\hline \multirow[t]{2}{*}{ Maandag } & Heeren & uur $16-18$ & 85 & 35 \\
\hline & $\begin{array}{l}\text { Populair } \\
\text { heeren }\end{array}$ & uur $21-221 / 2$ & 32 & 32 \\
\hline Dinsdag & $\begin{array}{l}\text { Dames } \\
\text { Heeren }\end{array}$ & $\begin{array}{l}\text { uur } 14-171 / 2 \\
\text { aur } 171 / 2-20\end{array}$ & $\begin{array}{r}134 \\
.14\end{array}$ & $\begin{array}{l}64 \\
37\end{array}$ \\
\hline
\end{tabular}

Het te verwachten bezoek (gebaseerd op de cijfers van de vooratgaande week) bedraagt 1000 , waarvan ongeveer 600 volwassenen. Zooals blijkt is getracht zooveel mogelijk alle "typen!" van baden in de enquête te betrekken.

Heeren

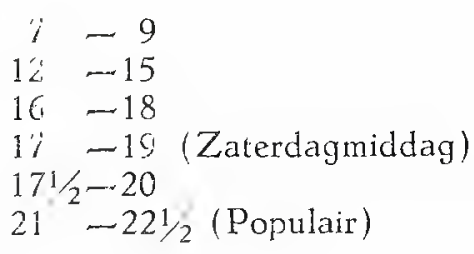

C. Litwoering.
Dames

$$
\begin{array}{ll}
9 & -151 / 2 \\
14 & -171 / 2 \\
15 & -17 \text { (Zaterdagmiddag) } \\
18 & -201 / 2 \\
201 / 2 & -22 \text { (Populair) }
\end{array}
$$

SITUATIE TEEKENING

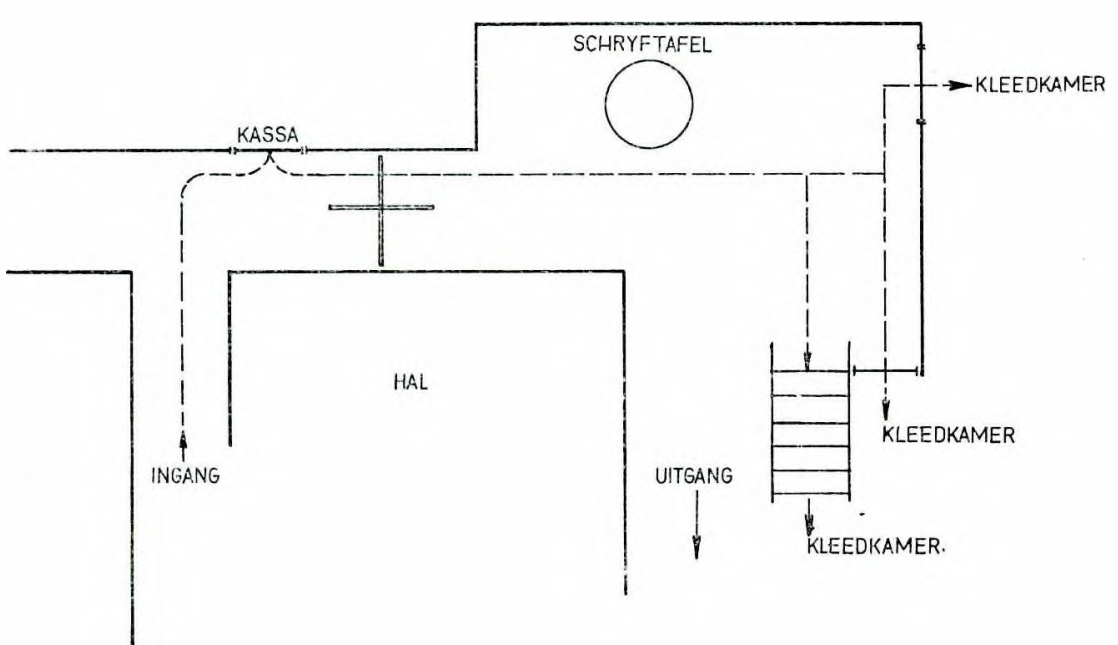

Het invulien van de formulieren.

Het formulier bleek nog tot eenig misverstand aanleiding te geven. De vluchtige lezer overziet de anduiding: , betreffend antwoord aanstrepen" en heeft de neiging alle antwoorden behalve het goede door te strepen. "iot moeilijkheder leidde dit echter niet, daar altijd het goede antwoord was op te maken.

Verder bleek, dat kinderen niei in staat waren her formulier zelfstandig in te vullen, terwijl ook betere restiltaten werden bereikt, wanneer voor volwassenen het formulier door de enquêteur werd ingevuld. Dit betreft de essentieele vraag van het formulier, n.1. hoeveel maal per jaar maakt U gebruik van het zwembad? De enquêteur trachte doot herhalde schattingen het werkelijk aanial in te slution.

b.v.:

"Hoeveel maal zwemt U per jaar?"

"Ik. kan niet zwemmen."

"Nu ja, hoeveel maal per jaar komt U hier baden?" "Elke week."

,Zoo, dus ongeveer vijftig mal per jaar. U zwemt dus LIw Vereenigingskinipkart vol.'
,O, dat niet, mijn vorige kaart was lang niet vol."

"In de wintermaanden koint U dan geregeld?"

"Neen, zoo af en toe."

,Dus U zwemt hier in de vier zomermaanden elke week en dan misschien zoo gemiddeld eens in de twee weken? Of zwemt UI in December en Januari heelemaal niet?"

"Midden in de winter kom ik toch ook wel eens."

"Kont Ul in de zomer nooit meer dan eenmaal per week?"

"Neen."

..Dan schat ik, dat U in de zomermaanden ongeveer 15 mal komt en in de 8 wintermaanden nog eens 15 maal, dat is een 30 keer per jaar."

.Ja, dat kan wel, maar deze winter wil ik elke week komen." .Dat doet er niet toe, dank U wel."

Hoewel een dergelijk vraaggesprek niet meer dan één minutut tijd kost is het niet mogelijk om op deze wijze tijdens de spitsuren te werk te gaan. Het onaangename is nu, dat dergelijke spitsen in de bezoekersstroom meer regel dan uitzondering zijn. Wij zijn er van uitgegaan, dat het publiek zoo weinig mogelijk last van de enquête moest ondervinden en dat wij de bezoekers niet konden verplichten om te wachten tot ze ondervraagd werden. 
De volgende maatregelen werden getroffen om het bezoek op de spitsuren zoo goed mogelijk te verwerken:

1. Een tweede enquêteur.

2. Kinderen worden niet ondervraagd.

3. De bezoekers, welke wachtten op de opening van het bad, werden van te voren ondervraagd.

Ad. 1: De tweede enquêteur beteekende een groote steun, maar de bezoekersstroom was in enkele gevallen zoo hoog, dat voor een goed doorgevoerde ondervraging geen tijd was. Aangezien de groote toevloed hoogstens een kwartier aanhoudt, is het aanstellen van meerdere enquêteurs weinig efficiënt.

Ad. 2: Daar de enquête viel binnen de periode der schoolvacantie, was het bezoek van kinderen op sommige oogenblikken zeer groot. Aangezien kinderen bij de enquête zonder uitzondering geholpen moesten worden en het verkrijgen van eenigszins betrouwbare antwoorden vaak langdurige ondervraging eischte, werd besloten in sommige periodes geen kinderen te ondervragen.

Ad. 3: Het groote aantal bezoekers, dat op Vrijdagavond en Zaterdagmiddag reeds een kwartier voor de opening van het bad in de hal stond te wachten, is tijdens dit wachten ondervraagd. Behalve dat dit ondervragen tengevolge van de drukte snel moest geschieden, was er in dit geval het nadeel, dat de bezoekers door elkaars antwoorden sterk beïnvloed konden worden.

\section{Resultaten.}

\section{T'oevallige- en systematische fouten.}

$B_{i j}$ de interpretatie van de resultaten dient men te overwegen, of men al of niet een ",fair sample" bereikt heeft.

Het "fair sample" wordt in ons geval in de eerste plaats bedreigd door de gedwongen keuze van de enquête-periode (zomer, vacantietijd), waardoor de wintermaanden niet onderzocht werden. In de conclusies is daarmede rekening gehouden. Zie eerste artikel.

Een andere systematische afwijking, welke ook bij een goed gekozen enquête-periode het resultaat min of meer zal beïnvloeden, doch thans door de korte duur van de enquête dit in sterkere mate doet, is deze, dat men meer kans heeft om een bader, welke vaak baadt aan te treffen, dan degene, welke slechts een gering gebruik maakt van het zwembad. Zoodoende wordt de categorie van degenen, welke veel zwem men, overschat ten koste van de categorie, welke minder baden per jaar neemt.

Wat betreft de systematische fout, ontstaan doordat men meer kans heeft de geregelde zwemmers te tellen dan de incidenteele, deze kan men theoretisch en practisch als volgt corrigeeren:

Bij iemand, die $200 \times$ per jaar zwemt, heeft men een kans 2 op 3 (200 op 300 werkdagen) dat men hem op de enquêtedag treft. De kans, dat men op dien dag iemand treft, welke gemiddeld $20 \times$ per jaar komt, is 2 op 30 , indien men tenminste de geheele dag telt en voor elke categorie zwemmers een gelijke verdeeling van het aantal baden over de dagen van het jaar aangenomen mag worden. Wanneer men meerdere dagen telt, b.v. 3 dagen, en men vult voor elke persoon slechts eenmaal een formulier in, dan worden de kansen iets anders. Degenen, die $200 \times$ per jaar komen zal men practisch alle tellen, terwijl ook degenen, welke $100 \times$ per jaar komen, voor een belangrijk deel zullen zijn geteld.

Beneden de $100 \times z$ ijn de kansen kleiner dan 1 . Bij $50 \times$ 1:2 enz. Al naar gelang het aantal enquêtedagen is een cor- rectietabel op te stellen. Men corrigeert door het aantal waarnemingen te vermenigvuldigen met omgekeerde van de kans. (tabel 1).

Tabel 1 .

\section{CORRECTIETABEL VOOR .,TREFKANS"}

Correctiefactor $\left(\frac{1}{\text { kans }}\right)$

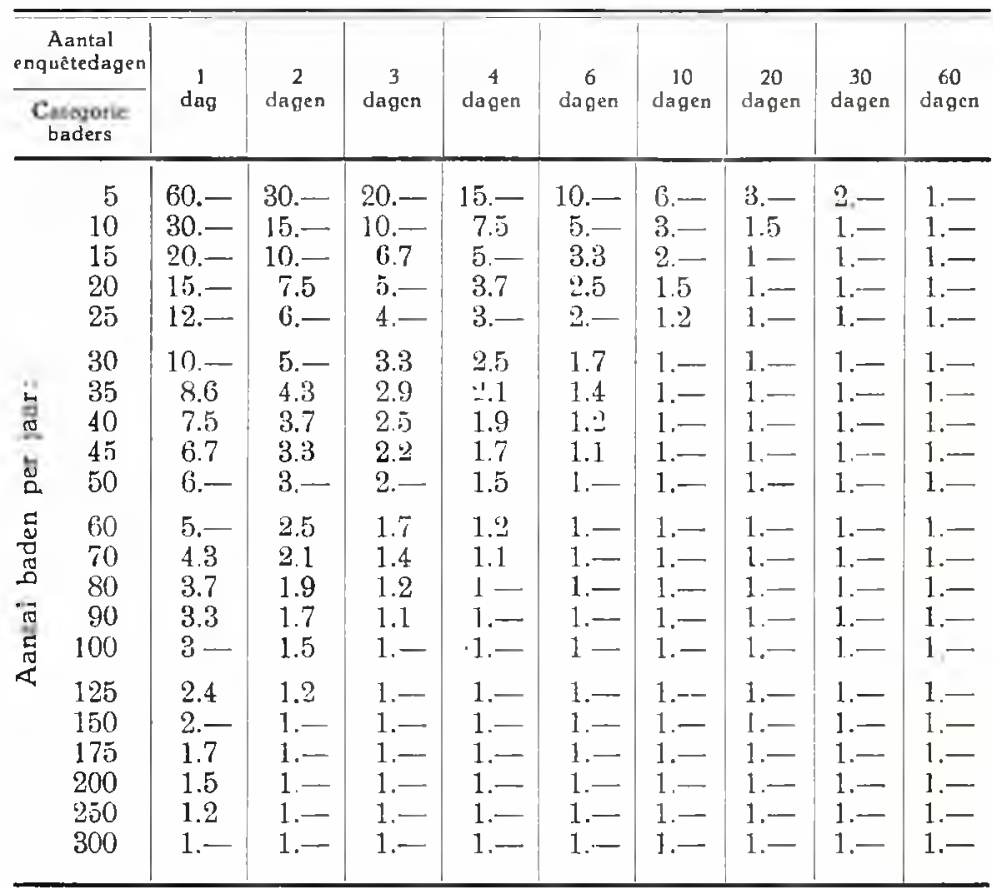

Deze correctietabel is, zooals gezegd, slechts toe te passen indien er geen groote verschillen tusschen het bezoek op verschillende dagen van de week optreden. Dit is niet geheel het geval (N.B. de ,weekzwemmers" op Zaterdag!). Als een eerste correctie zijn de cijfers echter zeer wel te gebruiken. Bovendien toont de tabel duidelijk aan, welke belangrijke correcties noodig zijn om tot een betrouwbaar beeld te geraken.

$\mathrm{Na}$ toepassing van de correctie krijgt men dus een betrouwbaar beeld van de verdeeling van het aantal bezoekers over de verschillende categorieën baders, b.v. baders, welke $\pm 5-$ maal, welke \pm 10 -maal, enz. per jaar komen. Men heeft dan een goed inzicht in de zwemgewoonte van de bezoekers gekregen. De verkregen cijfer's zijn uiteraard geen maatstaf van het aantal baden dat in totaal door elke bezoekscategorie genomen wordt. Al moet $30 \%$ van het aantal personen, dat het bad bezoekt gedurende een jaar, gerekend worden tot degenen welke niet meer dan 5-maal per jaar het bad bezoeken, het aantal baden dat door deze categorie bezoekers gebruikt wordt, vormt van het totaal een veel lager percentage.

Een psychologische fout ontstaat door de wijze van schatting. Men is nl. eerder geneigd zijn schatting af te ronden op tientallen dan op getallen, eindigende op 5 (25, 75 enz. uitgezonderd). Om deze fout te elimineeren is gewerkt met "gemiddelden" (zie hulpreeks Tabel 2), verkregen door telkens te nemen tweemaal het aantal waarnemingen in een bepaalde klasse, vermeerderd met het aantal waarnemingen van de twee aangrenzende klassen, b.v.

$\begin{array}{ccc}\text { Klasse: } & \begin{array}{c}\text { Waar- } \\ \text { genomen: }\end{array} & \\ 20 & 37 & \\ 25 & 51 & \text { Gecorrigeerd cijfer } 2 \times 51+37+56=195 \\ 30 & 56 & 2 \times 56+51+15=178 \\ 35 & 15 & \end{array}$




\begin{tabular}{|c|c|c|c|c|c|c|c|c|c|c|}
\hline \multirow{3}{*}{$\begin{array}{c}\text { Aantal } \\
\text { baden } \\
\text { per jaar } \\
\text { (Klasse) }\end{array}$} & \multicolumn{5}{|c|}{ Totaal ( 4 enquête-dagen) } & \multicolumn{5}{|c|}{$\begin{array}{l}\text { Totaal minus Vrijdagavond en Zaterdagmiddag } \\
\text { (3 enquête-dagen) }\end{array}$} \\
\hline & \multirow{2}{*}{$\begin{array}{c}\text { Werkelijk } \\
\text { geteld } \\
\text { aantal } \\
\text { bezockers }\end{array}$} & \multicolumn{2}{|c|}{$\begin{array}{l}\text { Gecorrigeerd voor } \\
\text { incidenteele afwijkingen }\end{array}$} & \multicolumn{2}{|c|}{$\begin{array}{c}\text { Tevens gecorrigeerd voor } \\
\text { systematische fout } \\
\text { (trefkans) }\end{array}$} & \multirow{2}{*}{$\begin{array}{c}\text { Werkelijk } \\
\text { geteld } \\
\text { aantal } \\
\text { bezoekers }\end{array}$} & \multicolumn{2}{|c|}{$\begin{array}{l}\text { Gecorrigeerd voor } \\
\text { incidenteele afwijkingen }\end{array}$} & \multicolumn{2}{|c|}{$\begin{array}{c}\text { Tevens gecorrigeerd voor } \\
\text { systematische fout } \\
\text { (trefkans) }\end{array}$} \\
\hline & & $\begin{array}{l}\text { Hulpreeks } \\
\qquad \text { 2) }\end{array}$ & $\%$ verdeeling & $\begin{array}{l}\text { Hulpreeks } \\
3 \text { 3) }\end{array}$ & $\%$ verdeeling & & $\begin{array}{l}\text { Hulpreeks } \\
\text { 2) }\end{array}$ & $\%$ verdeeling & $\begin{array}{l}\text { Hulpreeks } \\
3)\end{array}$ & $\%$ verdeeling \\
\hline 01) & 12 & 67 & 2.6 & $(5025)$ & $=$ & 9 & 54 & 4.0 & $(5400)$ & - \\
\hline $\begin{array}{r}5 \\
10 \\
15 \\
20 \\
25\end{array}$ & $\begin{array}{l}43 \\
22 \\
22 \\
37 \\
51\end{array}$ & $\begin{array}{l}120 \\
109 \\
103 \\
147 \\
195\end{array}$ & $\begin{array}{l}4.7 \\
4.3 \\
4.1 \\
5.8 \\
7.7\end{array}$ & $\begin{array}{r}1800 \\
817 \\
515 \\
551 \\
585\end{array}$ & $\begin{array}{r}25.2 \\
11.5 \\
7.2 \\
7.7 \\
8.2\end{array}$ & $\begin{array}{r}36 \\
12 \\
16 \\
28 \\
361\end{array}$ & $\begin{array}{r}73 \\
76 \\
72 \\
108 \\
140\end{array}$ & $\begin{array}{r}6.8 \\
5.6 \\
5.3 \\
7.9 \\
10.3\end{array}$ & $\begin{array}{r}1860 \\
760 \\
482 \\
540 \\
560\end{array}$ & $\begin{array}{r}31.1 \\
12.7 \\
8.1 \\
9.0 \\
9.4\end{array}$ \\
\hline $\begin{array}{l}30 \\
35 \\
40 \\
45 \\
50\end{array}$ & $\begin{array}{r}56 \\
15 \\
73 \\
23 \\
164\end{array}$ & $\begin{array}{l}178 \\
159 \\
184 \\
283 \\
355\end{array}$ & $\begin{array}{r}7.0 \\
6.3 \\
7.2 \\
11.1 \\
14.0\end{array}$ & $\begin{array}{l}445 \\
334 \\
350 \\
481 \\
532\end{array}$ & $\begin{array}{l}6.2 \\
4.7 \\
4.9 \\
6.7 \\
7.5\end{array}$ & $\begin{array}{r}40 \\
12 \\
44 \\
4 \\
38\end{array}$ & $\begin{array}{r}128 \\
108 \\
104 \\
90 \\
80\end{array}$ & $\begin{array}{l}9.4 \\
7.9 \\
7.7 \\
6.6 \\
5.9\end{array}$ & $\begin{array}{l}422 \\
313 \\
260 \\
198 \\
160\end{array}$ & $\begin{array}{l}7.1 \\
5.2 \\
4.4 \\
3.3 \\
2.7\end{array}$ \\
\hline $\begin{array}{l}55 \\
60 \\
65 \\
70 \\
75\end{array}$ & $\begin{array}{r}4 \\
20 \\
8 \\
25 \\
6\end{array}$ & $\begin{array}{r}192 \\
52 \\
61 \\
64 \\
62\end{array}$ & $\begin{array}{l}7.6 \\
2.0 \\
2.4 \\
2.5 \\
2.4\end{array}$ & $\begin{array}{r}250 \\
62 \\
67 \\
70 \\
62\end{array}$ & $\begin{array}{l}3.5 \\
0.9 \\
0.9 \\
1.0 \\
0.9\end{array}$ & $\begin{array}{r}- \\
8 \\
8 \\
16 \\
4\end{array}$ & $\begin{array}{l}46 \\
24 \\
40 \\
44 \\
42\end{array}$ & $\begin{array}{l}3.4 \\
1.8 \\
2.9 \\
3.2 \\
3.1\end{array}$ & $\begin{array}{l}83 \\
41 \\
60 \\
62 \\
55\end{array}$ & $\begin{array}{l}1.4 \\
0.7 \\
1.0 \\
1.0 \\
0.9\end{array}$ \\
\hline $\begin{array}{r}80 \\
85 \\
90 \\
95 \\
100 \\
105\end{array}$ & $\frac{25}{2} \frac{-}{30}$ & $\begin{array}{r}56 \\
27 \\
4 \\
32 \\
60 \\
30\end{array}$ & $\begin{array}{l}2.2 \\
1.1 \\
0.2 \\
1.3 \\
2.4 \\
1.2\end{array}$ & $\begin{array}{r}56 \\
27 \\
4 \\
32 \\
60 \\
30\end{array}$ & $\begin{array}{l}0.8 \\
0.4 \\
0.1 \\
0.4 \\
0.8 \\
0.4\end{array}$ & $\begin{array}{l}18 \\
- \\
- \\
13 \\
-\end{array}$ & $\begin{array}{l}40 \\
18 \\
- \\
13 \\
26 \\
13\end{array}$ & $\begin{array}{l}2.9 \\
1.3 \\
-1.0 \\
1.9 \\
1.0\end{array}$ & $\begin{array}{l}48 \\
20 \\
-13 \\
26 \\
13\end{array}$ & $\begin{array}{l}0.8 \\
0.3 \\
- \\
0.2 \\
0.4 \\
0.2\end{array}$ \\
\hline Totaal & 638 & 2540 & $100 .-$ & *)7130 & ») 100. & 342 & 1359 & 100.- & *) 5976 & \#) 100 \\
\hline $\begin{array}{l}\text { Hooger } \\
\text { dan } 105\end{array}$ & 50 & & & & & 28 & & & & \\
\hline Tot. Gen. & 688 & & & & & 370 & & & & \\
\hline
\end{tabular}

*) Zonder klasse 0 , welke tengevolge van vacantietijd buitensporig hoog bezet was.

1) Klasse 0 incidenteele zwemmers (logé's etc.).

¿) Hulpreeks ter correctie van incidenteele afwijkingen. Correctie verkregen door tweemaal middelste klasse te nemen en daarbij de aangrenzende klasse te tellen dus:

$$
\begin{array}{cccl} 
& \text { Klasse } & \text { Werkclijk } & \\
\text { b.v. Totaal } & 20 & 37 & \text { Gecorr. } 2 \times 51+37+56=195 \\
& 25 & 51 & \text { cijfer } \\
& 30 & 56 &
\end{array}
$$

Op deze wijze komt men tevens op eenvoudige wijze tegemoet aan de onjuistheid die ontstaat doordat men bij schatting meer geneigd is op tien-

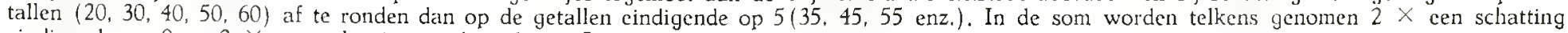
eindigende op $0 \mathrm{cn} 2 \times$ een schatting eindigende op 5 .

3) Zie tabel 1 .

In tabel 2 en grafiek 1 zijn de uitkomsten van de telling van het aantal baden per bezoekers per jaar gegeven. In beide gevallen zoowel voor de uitkomsten van de geheele enquête als van die zonder de Zaterdagmiddag en $V_{\text {rijdagavondtelling. }}$

In de tabel 2 treft men aan het werkelijk getelde aantal bezoekers, verdeeld volgens de baderscategorie (klasse) waartoe zij volgens hun opgave van het aantal baden per jaar behoorden. B.v. 51 bezoekers vulden in dat zij 25 maal per jaar van het bad gebruik maakten. In de eerste hulpreeks is op bovenomschreven wijze de correctie voor de schattingsfouten verwerkt, tevens is een procentueele verdeeling van deze hulpreeks gegeven. Vervolgens is aan de hand van de eerste hulpreeks en de gegeven correctietabel voor ",trefkans" een tweede hulpreeks berekend, waarin zoowel met de correctie voor schattingsfouten als met de correctie voor trefkans rekening is gehouden. Het cijfer 1800 voor de klasse 5 baden per jaar is b.v. verkregen door 120 te vermenigvuldigen met het geta! 15 (zic tabel 1, kolom 4 enquêtedagen, categorie 5 baden per jaar). Ook deze hulpreeks is weer omgezet in een procentueele verdeeling (de eerste categorie van incidenteele zwem- mers is buiten beschouwing gelaten!).

Deze procentueele verdeeling geeft nu aan de verdeeling van het totaal der bezoekers over de verschillende baderscategorieën. De cijfers zijn in fig. 1 in beeld gebracht. Men ziet daarin duidelijk, een top bij de klasse 25 baden per jaar. Voorts is de invloed van de Vrijdagavond en $\angle$ aterdagmiddag welke zich uit in een piek bij 50 baden per jaar, duidelijk zichtbaar. Op de andere dagen ontbreekt deze top geheel en al.

In tabel 3 zijn de uitkomsten van de gezinstelling gegeven. Ook hier treedt een systematische fout op bij de telling. Er is nl, cen grootere kans, dat men één van de leden van een gezin, bestaande uit een groot aantal gebruikers van het bad. treft dan dat men een lid treft van een gezin, dat maar één of twee gebruikers telt. Wij kunnen dus zeggen, dat de kans, dat men een lid van een familie met zes zwemmers treft, zes maal zoo groot is als de kans, dat men iemand treft, die als ,eenling" het zwembad bezoekt. Op basis van deze gedachte gang hebben wij dan ook in tabel 3 de werkelijk getelde cijfers gecorrigeerd voor deze ontmoetingskans. Wij merken, 
EGG.1

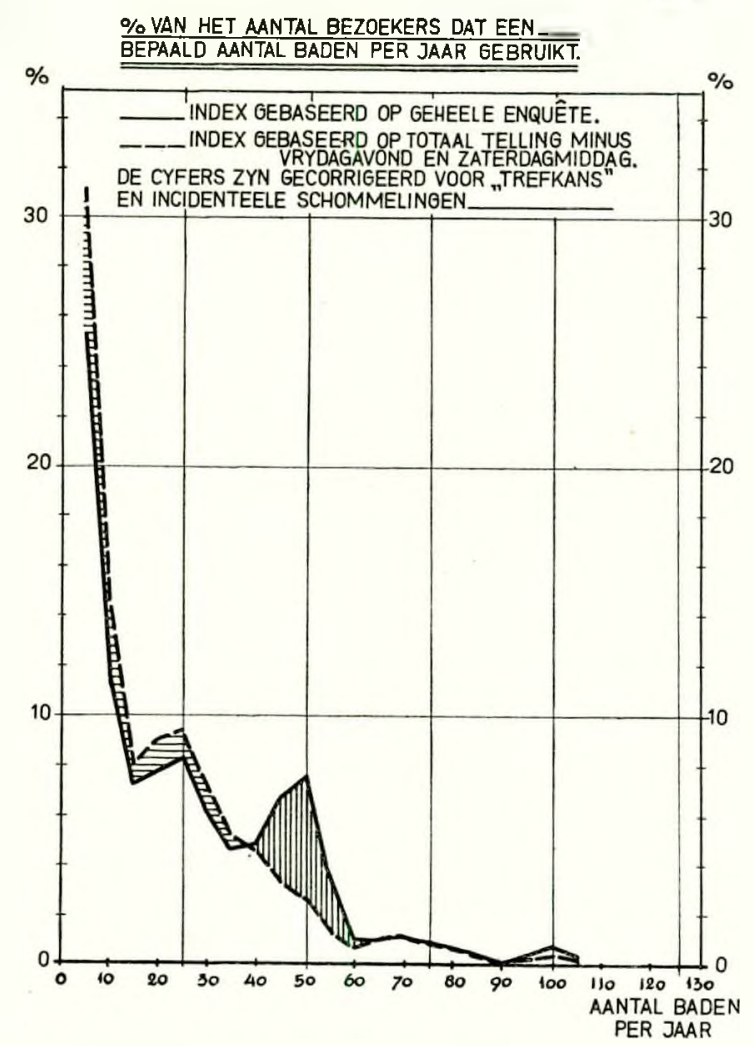

evenals bij de hiervoor genoemde correctie voor de systematische fout - "trefkans" - in de telling van het aantal bezoekers per bezoekerscategorie op, dat weliswar slechts $21 \%$ (zie tabel 3) van het aantal gezinnen, twee leden-zwemmers telt, naast $63 \%$ waarvan slechts één lid zwemt, doch dat dit niet beteekent, dat $63 \%$ van het aantal bezoekers uit eenlingen bestaat. De verhouding van het aantal bezoeken is bij wijze van spreken niet voor deze categorieën $63: 21$, doch $63: 42$.

Tabel 3

\section{GEZINSTELLING}

\begin{tabular}{c|c|c|c}
\hline \hline $\begin{array}{c}\text { Aantal andere leden dat } \\
\text { van de badinrichting ge- } \\
\text { bruik maakt }\end{array}$ & $\begin{array}{c}\text { Werkelijk } \\
\text { geteld aantal } \\
\text { gevallen }\end{array}$ & $\begin{array}{c}\text { Gerectificeerd } \\
\text { voor ontmoe- } \\
\text { tingskans } 1 \text { ) }\end{array}$ & $\begin{array}{c}\% \\
\text { verdeeling }\end{array}$ \\
\hline 0 & 261 & 261 & 63 \\
1 & 172 & 86 & 21 \\
2 & 105 & 35 & 8.5 \\
3 & 74 & 18 & 4.5 \\
4 & 38 & 8 & 2 \\
5 & 10 & 2 & 0.5 \\
6 & 17 & 1 & - \\
\hline 7 & 3 & - & - \\
\hline Totaal & 688 & 413 & 100. \\
\hline
\end{tabular}

1) Verkregen als volgt:

Categorie 0 ( 1 lid zwemt) $\quad \frac{261}{1}=261$

Categorie 1 ( 2 leden $z$ weinmen) $\frac{172}{2}=86$ enz, enz.

Voor gezinsreductie komen in aanmerking $\pm 40 \%$ v.h. aantal gezinnen. Het aantal leden dat daarvan voor gezinsreductie in aanmerking komt kan als volgt berekend worden:

$$
\begin{aligned}
& 63 \% \quad 0 \text { leden } \\
& 21 \% \quad 1 \text { lid } \\
& \text { enz. }
\end{aligned}
$$

Dit geeft gerelateerd aan het totaal aantal leden een gem. van $40 \%$ (zie berekening financieele risico's).
De conclusie uit deze cijfers is, dat in $84 \%$ van het aantal gezinnen niet meer dan 2 leden van het gezin van het bad gebruik maken. Dit cijfer wijkt ver af van de gezinsopbouw van de gemeente, waarin het zwembad is gelegen. Niet meer dan $30 \%$ der gezinnen bestaat uit alleenwonenden en gezinnen van 2 personen. Rekent men dat slechts de helft van het aantal personen van een ,zwemmend" gezin van het bad gebruik maakt, dan nog is het \% van het aantal gezinnen van 4 en minder personen van bijna $60 \%$ aanzienlijk lager dan $84 \%$. Wij mogen wel concludeeren, dat behalve dat het zwemmen slechts tot enkele leden van het gezin is doorgedrongen, door de groote gezinnen relatief weinig van het bad gebruik gemaakt wordt.

Dr. J. G. STRIDIRON

\section{NIEUWS IN ZAKE WETGEVING, RESOLUTIESEN BESLISSINGEN OP HET GEBIED DER BELASTINGEN \\ Red.: Mr Dr E. TEKENBROEK}

(Bijdragen en mededeelingen zende men aan den Secretaris der Redactie)

\section{Goed koopmansgebruik en de cassatierechter}

Een N.V. had een dividend-uitkeering gedaan t.l.v. het agio (dus t.l.v. het kapitaal) en claimde op die grond vrijstelling van dividendbelasting, daar goed koopmansgebruik vorderde, dat die betaling t.l.v. het kapitaal geschiedde. De Inspecteur was met den belastingplichtige van meening, dat goed koopmansgebruik vorderde de onderhavige dividenduitkeering ten laste van het agio te doen. Daaromtrent was dus tusschen partijen geen geschil. Desniettemin besliste de Amsterdamsche Raad van Beroep ambtshalve, dat goed koopmansgebruik niet vorderde, dat de uitkeering t.l.v. het agio geschiedde.

De in het ongelijk gestelde N.V. ging in cassatie en stelde o.m. dat de Raad van Beroep buiten het hem voorgelegde geschil was getreden en dus art. 16 W.R.v.B. had geschonden.

De H.R. achtte dit middel echter ongegrond, daarbij in zijn arrest dd. 15 Nov. '39 (B 7024) o.m. overwegende:

..dat toch de omstandigheid, dat beide partijen van mee.ning waren, dat de vraag, of in dit geval goed koopman,schap vorderde, dat het aan aandeelhouders uitgekeerde be"drag van f 25.800. - ten laste van het agio (kapitaal) werd .gebracht, bevestigend moest worden beantwoord, den raad ,van beroep geenszins onthief van zijn plicht deze vraag ,voor de in geschil zijnde uitdeeling zelfstandig, onafhan„,kelijk van de meening van partijen, te onderzoeken en te be,oordeelen:

",dat toch deze eenstemmigheid tusschen partijen niet be,trof een feit, doch omvatte een juridisch cordeel omtrent de ,vraag, welke beteekenis dient te worden toegekend aan de ,aan art. 5 eerste lid, letter b, toegevoegde zinsnede, bevat,tende eene uitzondering op den regel, dat terugbetaling van .,kapitaal, indien en voor zoover er winst is, als uitdeeling "van winst moet worden beschouwd;"

Deze overweging lijkt ons in verband met de wet op de winstbelasting bij wier toepassing de vaststelling of een bepaalde handelswijze al of niet in overeenstemming is met het goed koopmansgebruik, van belang. Deze overweging zou er op kunnen wijzen, dat de H.R. het oordeel van een Raad van Beroep, dat een bepaalde handeling al of niet in overeenstemming met het goed koopmansgebruik is, als zijnde een juridisch oordeel voor cassatie vatbaar acht. Zekerheid be- 